\title{
Teškoće u unapređenju nauke i oblikovanju sistema nauke i univerziteta kao nosioca tehnološkog razvoja u Bosni i Hercegovini
}

\author{
Dejan Milošević \\ Benjamin Fetic ${ }^{* *}$
}

\begin{abstract}
Apstrakt: Osnovna funkcija univerziteta, pored obrazovanja, je naučnoistraživački rad. Na bosanskohercegovačkim univerzitetima je naučnoistraživački rad zapostavljen. Dva su osnovna razloga za to. Prvi je nedovoljno finansijsko ulaganje u nauku i istraživanja, a drugi je nedovoljno razvijena svijest o značaju naučnoistraživačkog rada, kako u bosanskohercegovačkom društvu, tako i na samim univerzitetima. U ovom radu je ukazano na to šta je potrebno uraditi da se ova druga teškoća prevaziđe. Pored toga, analizirane su mogućnosti unapređenja nauke i oblikovanja sistema nauke na bosanskohercegovačkim univerzitetima, kako bi oni postali i istraživački univerziteti. Na naučnoistraživački rad se nadovezuju istraživačko-razvojni rad, tehnološki razvoj, saradnja s privredom i razvoj naučno-tehnoloških parkova. Ove djelatnosti su još manje zastupljene na bosanskohercegovačkim univerzitetima nego naučnoistraživački rad. U ovom radu je ukazano na načine kako prevazići te teškoće, kako bi istraživački univerziteti postali nosioci tehnološkog razvoja Bosne i Hercegovine.
\end{abstract}

Ključne riječi: bosanskohercegovački univerziteti, nauka, istraživanje, razvoj, tehnologija

\section{Uvod}

U Bosni i Hercegovini postoji osam javnih univerziteta, šest u entitetu Federacija Bosne i Hercegovine u pet kantona (Univerzitet u Sarajevu, Univerzitet u Bihaću, Univerzitet „Džemal Bijedić“ u Mostaru, Sveučilište u Mostaru, Univerzitet u Tuzli i Univerzitet u Zenici) i dva u entitetu Republika Srpska (Univerzitet u Banjoj Luci i Univerzitet u Istočnom Sarajevu). Privatnih univerziteta u Bosni i Hercegovini ima ukupno osamnaest, od čega devet u Federaciji Bosne i Hercegovine, sedam u entitetu Republika Srpska i dva u distriktu Brčko. Pored toga, u Bosni i Hercegovini djeluje šesnaest

\footnotetext{
${ }^{*}$ Redovni član Akademije nauka i umjetnosti Bosne i Hercegovine i redovni profesor na Prirodno-matematičkom fakultetu Univerziteta u Sarajevu. E-mail: milo@bih.net.ba

${ }^{* *}$ Doc. dr., Prirodno-matematički fakultet Univerziteta u Sarajevu.

E-mail: benjamin.fetic@pmf.unsa.ba
} 
samostalnih fakulteta i visokih škola u privatnom vlasništvu. Nažalost, nema podataka o tome u kojoj se mjeri ove institucije bave naučnoistraživačkim radom. ${ }^{1}$ Nijedan javni ili privatni univerzitet nema u svom sastavu jedinice koje su proglašene centrima izvrsnosti. Povezanost ovih institucija sa privredom je ocijenjena kao nedovoljna (Trifković, 2020).

Naučna istraživanja se klasifikuju kao fundamentalna, primijenjena i razvojno-istraživačka (Trifković, 2020). Uz obrazovanje, naučnoistraživački rad je osnovna funkcija univerziteta. Nažalost, na bosanskohercegovačkim univerzitetima naučnoistraživački rad je zapostavljen. To se može uvidjeti kroz analizu položaja bosanskohercegovačke nauke i bosanskohercegovačkih univerziteta na svjetskim rang listama. U okviru projekta „Harmonizacija sistema nauke u Bosni i Hercegovini“ (Trifković, 2020) Akademije nauka i umjetnosti Bosne i Hercegovine pokazano je da je glavni razlog nezadovoljavajućeg stanja nauke u Bosni i Hercegovini njena policentrična i atrofirana organizacija. Predložene mjere za poboljšanje stanja nauke baziraju se na harmonizaciji sistema nauke putem zakonodavstva nadležnih političko teritorijalnih jedinica. Ukazano je na to da je, pored usklađivanja postojećih i donošenja novih zakona, potrebno revidirati postojeće strategije, pojačati i modernizovati odgovarajuće kapacitete javne uprave, odvojiti budžetsko finansiranje naučnoistraživačke i tehnološko-razvojne djelatnosti od finansiranja nastavne komponente visokog obrazovanja, znatno povećati izdvajanja za nauku u odnosu na trenutnih $0,1 \%$ bruto nacionalnog dohotka, odrediti prioritete u međunarodnoj saradnji i formirati savjete za nauku.

Većina gore navedenih predloženih mjera za poboljšanje položaja nauke su „top-down“ tipa. Predviđeno je da se odluke donose na višem nivou (npr. promjena zakona, donošenje strategija) uz očekivanja da će to dovesti do željenih promjena. Nažalost, realnost bosanskohercegovačkog društva je takva da se zakoni različito interpretiraju, a strategije ne sprovode. Vlasti ne shvataju koliko je nauka važna za društvo. Ne postoji državno ministarstvo za nauku jer je, prema Ustavu Bosne i Hercegovine, obrazovanje, zajedno s naučnoistraživačkim radom, u nadležnosti kantona u Federaciji Bosne i Hercegovine, odnosno entiteta Republika Srpska. Zakonska regulativa zavisi od nivoa vlasti, tako da se donose parcijalna rješenja. Ne postoji politika nadležnih institucija za povratak u domovinu najboljih studenata koji su otišli iz Bosne i Hercegovine u svrhu obrazovanja. Kadrovska politika univerziteta

\footnotetext{
${ }^{1}$ Vidjeti: Odgovori na Upitnik Evropske komisije - Poglavlje 25 - Nauka i istraživanje, Direkcija za evropske integracije Vijeća ministara Bosne i Hercegovine, DEI | Odgovori na Upitnik EK. (2. 11. 2020)
} 
je neadekvatna, odnosno praktično ne postoji. Ovaj rad ukazuje na mogućnost drugačijeg pristupa. „Bottom-up“ pristup bi trebao postepeno dovesti do promjene svijesti vlasti i pojedinaca o značaju nauke i naučnoistraživačkog rada za razvoj bosanskohercegovačkog društva. Potrebno je stvoriti kritičnu masu naučnika koji se zaista bave naučnoistraživačkim radom, što se može izmjeriti egzaktnim pokazateljima utvrđenim međunarodnim standardima i kriterijima, kao što su to broj i kvalitet objavljenih radova koje prati baza podataka Web of Science Core Collection, h-index i sl.

Nakon ovoga uvoda, u narednim poglavljima su prvo predstavljeni egzaktni pokazatelji o položaju bosanskohercegovačke nauke i bosanskohercegovačkih univerziteta u svijetu. Dobijeni rezultati su bazirani na analizi pažljivo odabranih svjetskih rang listi. Nakon toga su predstavljeni Strategija razvoja naučnoistraživačkog/umjetničkoistraživačkog rada na Univerzitetu u Sarajevu i Pravilnik o nagrađivanju akademskog i naučnoistraživačkog osoblja Univerziteta u Sarajevu na osnovu rezultata naučnog/umjetničkog rada kao primjeri „bottom-up“ mjera za poboljšanje položaja nauke u Bosni i Hercegovini. Prikazat će se i rezultati analize broja i citiranosti radova s afilijacijom Univerziteta u Sarajevu. U preostalom dijelu rada su predstavljeni podaci o institutima, naučnoistraživačkim centrima, tehnološkim parkovima i patentima u Bosni i Hercegovini. Ukazano je na slabosti sistema prikupljanja podataka o naučnoistraživačkom radu. Finansiranje i problemi realizacije zapošljavanja naučnika i istraživača su razmotreni neposredno prije zaključaka s kojima se ovaj rad završava.

\section{Položaj bosanskohercegovačke nauke u svijetu}

Položaj nauke neke države u svijetu se utvrđuje prema doprinosu naučnika te države naučnoj produkciji izraženoj brojem i značajem naučnih publikacija. Postoje različite rang liste država. ${ }^{2}$ Npr. Nature index ${ }^{3}$ je baza podataka zasnovana na radovima objavljenim u izabranoj grupi od 82 visokokvalitetna časopisa. S obzirom da je broj takvih radova objavljenih od bosanskohercegovačkih autora zanemarljiv, opredijelili smo se za analizu podataka dostupnih

\footnotetext{
${ }^{2}$ Akademska rangiranja, Agencija za znanost i visoko obrazovanje, Zagreb, 2019. (brošura tiskana u okviru projekta SKAZVO: https://skazvo.azvo.hr/images/stories/dokumenti/24 Bro\%C5\%A1ura_Akademska_rangiranja.pdf).

${ }^{3} \mathrm{https}: / /$ www.natureindex.com/
} 
na The SCImago Journal \& Country Rank portalu. ${ }^{4}$ Analizom objavljivanja i citiranja u preko 34 hiljade naslova prema specifičnom algoritmu (GuerreroBotea \& Moya-Anegón, 2012) rangirano je 239 država. Redoslijed za 2020. godinu je: Kina, Sjedinjene Američke Države, Velika Britanija, Indija, Njemačka, Italija, Japan, Francuska, Kanada, Ruska Federacija, Australija, Španija itd. Tabela 1 prikazuje položaj Bosne i Hercegovine na osnovu objavljenih naučnih radova prema SCImago Journal\&Country Rank u periodu od 1996. do 2020. godine. Navedeno je i rangiranje država u našem okruženju. Zaključak je da znatno zaostajemo u odnosu Srbiju, Hrvatsku i Sloveniju, ali da smo bolji od Makedonije, Crne Gore i Albanije. Uzimajući u obzir prijeratni razvoj ovih država, ovaj rezultat je očekivan. Interesantno je uočiti da se, za razliku od država u okruženju, položaj Bosne i Hercegovine na ovoj rang listi popravio u zadnjim godinama. Ipak, razlika za preko trideset mjesta na svjetskoj rang listi u odnosu na Srbiju, Hrvatsku i Sloveniju je prevelika i može se pripisati lošem odnosu bosanskohercegovačkih vlasti prema nauci i naučnoistraživačkom radu, kao i nedovoljno razvijenoj svijesti članova akademske zajednice o značaju naučnoistraživačkog rada.

Tabela 1. Rangiranje Bosne i Hercegovine i država u njenom okruženju u periodu 1996-2020. prema SCImago Journal \& Country Rank portalu (1. 6. 2021)

\begin{tabular}{lccccccc}
\hline & $1996-2020$. & 2015. & 2016. & 2017. & 2018. & 2019. & 2020. \\
\hline BiH & 96 & 92 & 92 & 92 & 93 & 92 & 92 \\
\hline Srbija & 52 & 50 & 51 & 51 & 54 & 54 & 56 \\
\hline Hrvatska & 50 & 52 & 53 & 53 & 55 & 59 & 58 \\
\hline Slovenija & 53 & 53 & 55 & 55 & 59 & 60 & 60 \\
\hline Makedonija & 97 & 93 & 95 & 95 & 95 & 98 & 101 \\
\hline Crna Gora & 122 & 118 & 112 & 111 & 114 & 112 & 114 \\
\hline Albanija & 118 & 107 & 117 & 126 & 116 & 118 & 119 \\
\hline
\end{tabular}

\section{Položaj bosanskohercegovačkih univerziteta na Webometricsovoj listi}

U zadnjih nekoliko godina rukovodstvo Univerziteta u Sarajevu je uložilo značajan napor kako bi univerzitet napredovao na svjetskim rang-listama. Ovo se posebno odnosi na Webometricsovu rang listu koja uključuje sve univerzitete u svijetu. Naime, akademsko osoblje Univerziteta u Sarajevu publikuje zanemarljivo malo radova u vrhunskim naučnim časopisima, tako

\footnotetext{
${ }^{4}$ https://www.scimagojr.com. Ovaj portal koristi informacije baze podataka Scopus ${ }^{\circledR}$ (www. scopus.com; Elsevier B.V.: www.elsevier.com).
} 
Dejan Milošević, Benjamin Fetić: Teškoće u unapređenju nauke i oblikovanju sistema nauke i univerziteta...

da Univerzitet u Sarajevu uopšte nije rangiran na prestižnim svjetskim rang listama kao što je Shanghai lista. ${ }^{5}$ Pri rangiranju po Webometricsu koriste se četiri kriterija prema Tabeli 2.

Tabela 2. Kriteriji za rangiranje prema Webometricsu.

\begin{tabular}{|c|c|c|c|}
\hline INDIKATORI & OPIS & IZVOR & UDIO \\
\hline PRISUTNOST (PRESENCE) & $\begin{array}{l}\text { Veličina web domene institucije (s pod-domenama) - uključuje } \\
\text { i broj dokumenata postavljenih na domenu i pod-domene u vidu } \\
\text { rich teksta, pdf. }\end{array}$ & Google & $5 \%$ \\
\hline VIDLJIVOST (VISIBILITY) & $\begin{array}{l}\text { Vidljivost (broj pojavljivanja linka web stranice institucije na web } \\
\text { stranicama drugih institucija). }\end{array}$ & $\begin{array}{l}\text { Ahrefs } \\
\text { Majestic }\end{array}$ & $50 \%$ \\
\hline $\begin{array}{l}\text { OTVORENOST } \\
\text { (TRANSPARENCY or } \\
\text { OPENNESS) }\end{array}$ & $\begin{array}{l}\text { Broj citata top } 10 \text { autora institucije na Google Scholaru } \\
\text { (sabiraju se citati od drugog do desetog rangiranog autora, dok se } \\
\text { broj citata prvog ne sabira). }\end{array}$ & $\begin{array}{l}\text { Google } \\
\text { Scholar } \\
\text { Citations }\end{array}$ & $10 \%$ \\
\hline $\begin{array}{l}\text { IZVRSNOST (EXCELLENCE } \\
\text { or SCHOLAR) }\end{array}$ & $\begin{array}{l}\text { Broj objavljenih radova među 10\% najcitiranijih radova u } 26 \\
\text { disciplina u periodu od pet godina. }\end{array}$ & Scimago & $35 \%$ \\
\hline
\end{tabular}

Prema Webometrics listi iz jula 2020. godine redoslijed univerziteta iz našeg regiona je sljedeći (u zagradi je rang u svijetu): 1. Ljubljana (314), 2. Beograd (441), 3. Zagreb (590), 4. Novi Sad (934), 5. Split (1098), 6. Maribor (1118), 7. Niš (1397), 8. Rijeka (1420), 9. Sarajevo (1508). Među prvih 2000 univerziteta su i: Skoplje (1556), Kragujevac (1750), Univerzitet Crne Gore (1915) i Osijek (1993). Prema očekivanju, univerziteti u Ljubljani, Beogradu i Zagrebu su daleko ispred Univerziteta u Sarajevu koji je najbolje plasirani bosanskohercegovački univerzitet. Prema tradiciji i prijeratnom položaju, Univerzitet u Sarajevu bi trebao biti u rangu Univerziteta u Novom Sadu, a ispred Univerziteta u Splitu, Mariboru, Nišu i Rijeci. Ostali univerziteti u Bosni i Hercegovini su rangirani ispod 3000. mjesta (vidjeti Tabelu 3). Dakle, jasno je da su univerziteti u Bosni i Hercegovini, koji bi trebali biti nosioci nauke i naučnoistraživačkog rada, rangirani daleko ispod očekivanja. Taj zaostatak je još i veći ako se uzme u obzir samo kriterij naučne izvrsnosti (kriterij „excelence“ doprinosi 35\% prema Tabeli 2; uporediti zadnju kolonu u Tabeli 3). Razlozi za ovaj neuspjeh bosanskohercegovačke nauke su navedeni u Uvodu.

\footnotetext{
${ }^{5} \mathrm{http}: / /$ www.shanghairanking.com/
} 
Posebna izdanja ANUBiH CC, ODN knjiga 18, str. 163-179

Tabela 3. Rang lista prvih 14 univerziteta u Bosni i Hercegovini prema Webometricsu.

\begin{tabular}{ccccccc}
\hline Ranking & World & University & Presence & Impact & Openness & Excellence \\
\hline 1 & 1508 & Univerzitet u Sarajevu & 905 & 1979 & 1209 & 2214 \\
\hline 2 & 3107 & Univerzitet u Tuzli & 1228 & 5553 & 1870 & 4011 \\
\hline 3 & 3604 & International University of Sarajevo & 1120 & 6976 & 3472 & 4064 \\
\hline 4 & 3800 & International BURCH University Sarajevo & 3767 & 7529 & 3762 & 4011 \\
\hline 5 & 3882 & Univerzitet u Banjoj Luci & 970 & 5861 & 5819 & 3383 \\
\hline 6 & 4767 & Sveučilište u Mostaru & 940 & 12342 & 2531 & 4942 \\
\hline 7 & 5478 & Univerzitet u Istočnom Sarajevu & 1871 & 20450 & 2883 & 4011 \\
\hline 8 & 6463 & Sarajevo School of Science \&Technology & 17018 & 12688 & 4394 & 5379 \\
\hline 9 & 6732 & Evropski Univerzitet „Kallos“ Tuzla & 11938 & 4117 & 5593 & 6626 \\
\hline 10 & 6881 & Evropski univerzitet Brčko & 10345 & 3724 & 5819 & 6626 \\
\hline 11 & 8378 & Univerzitet u Bihaću & 9031 & 13550 & 5018 & 5902 \\
\hline 12 & 9240 & Univerzitet „Džemal Bijedić ${ }^{\prime \prime}$ Mostar & 7267 & 11634 & 4329 & 6626 \\
\hline 13 & 10866 & Internacionalni Univerzitet Travnik & 12903 & 8983 & 5819 & 6626 \\
\hline 14 & 11916 & Univerzitet u Zenici & 3519 & 23196 & 3706 & 5681 \\
\hline
\end{tabular}

Napominjemo da je najnoviji položaj Univerziteta u Sarajevu na 1508. mjestu u svijetu najbolji do sada. To je rezultat napornog rada na povećanju prisustva i vidljivosti web prostora Univerziteta u Sarajevu (izrada nove web stranice) i zahtjeva da se akademsko osoblje i istraživači registruju na Google scholar. ${ }^{6}$ To se vidi i po tome što je Univerzitet u Sarajevu znatno bolje rangiran po prisutnosti (905) i transparentnosti (1209). Ovo je ostvareno u relativno kratkom vremenskom periodu. Univerzitet u Sarajevu zaostaje po kriteriju utjecaja (1979) (ovaj kriterij nosi 50\%; pojednostavljeno rečeno, pri izračunavanju ovog kriterija računaju se svi vanjski linkovi koje web domena univerziteta dobija od trećih strana). Ovi rezultati ukazuju da je moguće poboljšati položaj nauke u Bosni i Hercegovini i „bottom-up“ pristupom. Pored Univerziteta u Sarajevu, na sličan način se planira popraviti položaj drugih univerziteta. ${ }^{7}$ Očito je da Univerzitet u Sarajevu najviše zaostaje po kriteriju izvrsnosti (2214. mjesto) koji doprinosi 35\% ukupnom rangiranju. Poboljšanje izvrsnosti je moguće ostvariti samo dugoročnim mjerama. Tu, naravno, spadaju „top-down“ mjere, spomenute u uvodu. Primjer dugoročnih „,bottom-up“ mjera su Strategija razvoja naučnoistraživačkog/umjetničkoistraživačkog rada na Univerzitetu u Sarajevu i Pravilnik o nagrađivanju

\footnotetext{
${ }^{6} \mathrm{https}: / /$ scholar.google.com/

${ }^{7}$ Milošević, D. Uloga, značaj, promocija i popularizacija nauke u BiH: Primjer Univerziteta u Sarajevu, predavanje, Univerzitet „Džemal Bijedić“ Mostar, 24. decembar, 2019.; kontakti s kolegama s Univerziteta u Tuzli itd.
} 
Dejan Milošević, Benjamin Fetić: Teškoće u unapređenju nauke i oblikovanju sistema nauke i univerziteta...

akademskog i naučnoistraživačkog osoblja Univerziteta u Sarajevu na osnovu rezultata naučnog/umjetničkog rada o kojima će biti riječi u narednim dijelovima rada.

\section{Strategija razvoja naučnoistraživačkog/umjetničkoistraživačkog rada na Univerzitetu u Sarajevu}

Savjet za nauku i umjetnost Univerziteta u Sarajevu je stručno i savjetodavno tijelo Senata Univerziteta u Sarajevu imenovano odlukom Senata od 28. 12. 2016. godine. Osnovni dokument relevantan za ovaj rad je Strategija razvoja naučnoistraživačkog/umjetničkoistraživačkog rada na Univerzitetu u Sarajevu koja je usvojena 22.9. 2017. na sjednici Senata na prijedlog Savjeta. ${ }^{8}$ Ovom strategijom je predviđeno da se izvrsna istraživanja i objavljivanje kvalitetnih publikacija posebno podstiču i nagrađuju. U drugom poglavlju te strategije (2. Kreiranje kriterija naučne izvrsnosti i relevantnosti) u dijelu „Novi kriteriji za izbore u zvanja i podsticaji izvrsnim istraživačima“ navodi se da: „U naučne radove treba ubrajati radove objavljene u naučnim časopisima zastupljenim u bazi podataka WoSCC (Web of Science Core Collection). Pri izradi pravilnika o izboru u akademska zvanja kojim će se uspostaviti bodovni sistem vrednovanja naučnih radova kao uslova za izbor u akademska zvanja posebnu pažnju posvetiti izvještajima o citiranosti JCR (Journal Citation Reports) i SJR (SCImago Journal Rank indicator) i, u skladu s tim, naučne časopise razvrstati po značaju koji imaju u svojoj oblasti (npr. u tzv. kvartile Q1, Q2, Q3 i Q4).“

U zaključku Strategije razvoja naučnoistraživačkog/umjetničkoistraživačkog rada na Univerzitetu u Sarajevu je naglašeno da su ključni elementi za provođenje ove strategije:

,- formiranje registara naučnih/umjetničkih radova, istraživača/umjetnika, projekata i infrastrukture,

- aktiviranje/osnivanje centra za istraživanje i razvoj Univerziteta u Sarajevu (i u okviru njega naučnotehnološkog parka),

- novi kriteriji za izbore u zvanja i podsticaji izvrsnim istraživanjima,

- reforme i unapređenje doktorskog studija kao bitnog segmenta naučnoistraživačkog rada i općenito razvoja akademske zajednice,

- racionalizacija postojeće naučnoistraživačke infrastrukture i planska nabavka krucijalne opreme.“

\footnotetext{
${ }^{8}$ https://www.unsa.ba/index.php/istrazivanje-i-saradnja/istrazivanje/strategija
} 
Navedeni registri još nisu formirani. Centar za istraživanje i razvoj UNSA je osnovan, ali još nije aktiviran. Kriteriji za podsticaje izvrsnim istraživačima su usvojeni i izvrsni istraživači su nagrađeni za rezultate u 2017, 2018. i 2019. godini. Pravilnik o kriterijima za izbore u zvanja tek treba napraviti i usvojiti. Usvojena su nova pravila doktorskog studija. Za racionalizaciju postojeće naučnoistraživačke infrastrukture i plansku nabavku krucijalne opreme potrebno je prvo formirati registar i na osnovu njega napraviti odgovarajuću analizu.

\section{Pravilnik o nagrađivanju akademskog i naučnoistraživačkog osoblja Univerziteta u Sarajevu na osnovu rezultata naučnog/umjetničkog rada}

Kao sljedeći primjer „bottom-up“ poboljšanja kvaliteta i položaja nauke navodi se Pravilnik o nagrađivanju akademskog i naučnoistraživačkog osoblja Univerziteta u Sarajevu na osnovu rezultata naučnog/umjetničkog rada. ${ }^{9}$ Senat Univerziteta u Sarajevu je donio ovaj pravilnik na 19. sjednici održanoj 29. 5. 2018. godine. Prije donošenja pravilnika napravljena je analiza radova objavljenih u 2017. godini s afilijacijom Univerziteta u Sarajevu prema bazi podataka Web of Science Core Collection. Na osnovu rezultata te analize pravilnik je koncipiran tako da se postigne što ravnopravnije vrednovanje doprinosa naučnika iz različitih oblasti. U Tabelama 4, 5 i 6 su predstavljeni rezultati za 2017, 2018. i 2019. godinu. ${ }^{10}$ Za svaku grupaciju nauka i svaku organizacionu jedinicu predstavljen je broj radova objavljenih u časopisima kojima je pridružena određena kvartila (Q1, Q2, Q3 i Q4). ${ }^{11}$

\footnotetext{
9 https:/www.unsa.ba/o-univerzitetu/propisi/pravilnik-o-nagradivanju-akademskog-i-naucnoistrazivackog-osoblja

${ }^{10}$ Podatke u datim tabelama je obradila Služba za naučnoistraživački rad Univerziteta u Sarajevu.

${ }^{11}$ Rangiranje po kvartilima (quartile ranking) je bazirano na impakt faktoru (IF) časopisa prema Journal Citation Reports (JCR) koji izdaje Clarivate Analytics svake godine. Informacije se mogu dobiti preko Web of Science Core Collection. Q1 se pridružuje najboljim časopisima (rangiranih u prvih 25\%), Q2 odgovara 25-50\%, Q3 - 50-75\%, a Q4 zadnjih 75-100\% časopisa prema IF-u.
} 
Dejan Milošević, Benjamin Fetić: Teškoće u unapređenju nauke i oblikovanju sistema nauke i univerziteta...

Tabela 4. Lista broja objavljenih radova i bodovi za 2017. godinu po grupacijama $i$ organizacionim jedinicama Univerziteta u Sarajevu prema Pravilniku o nagrađivanju.

\begin{tabular}{|c|c|c|c|c|c|c|c|c|c|c|c|c|c|}
\hline GRUPACIJA & $\begin{array}{c}\text { Organizaciona } \\
\text { jedinica/institucija }\end{array}$ & Wos Docs & $\begin{array}{c}\text { Docs in JIF } \\
\text { Journals }\end{array}$ & $\begin{array}{c}\text { Docs in } \\
\text { Q1 } \\
\text { Journals }\end{array}$ & $\begin{array}{c}\text { Docs in } \\
\text { Q2 } \\
\text { Journals }\end{array}$ & $\begin{array}{c}\text { Docs in } \\
\text { Q3 } \\
\text { Journals } \\
\end{array}$ & $\begin{array}{c}\text { Docs in } \\
\text { Q4 } \\
\text { Journals }\end{array}$ & $\begin{array}{l}\text { Docs } \\
\text { other } \\
\text { than JIF }\end{array}$ & Q1 (10) & Q2 (7) & Q3 (4) & $\mathrm{Q} 4(2)$ & $\begin{array}{l}\text { UKUPNO } \\
\text { BODOVA }\end{array}$ \\
\hline \multirow{2}{*}{ Društvene nauke } & Ekonomski fakultet & 25 & 13 & 3 & 5 & 3 & 2 & 12 & 30 & 35 & 12 & 4 & 93 \\
\hline & \begin{tabular}{|l|} 
Pravni fakultet \\
\end{tabular} & 1 & 0 & 0 & 0 & 0 & 0 & 1 & 0 & 0 & 0 & 0 & 1 \\
\hline \multirow{2}{*}{ Humanističke nauke } & Filozofski fakultet & 6 & 3 & 0 & 2 & 1 & 0 & 3 & 0 & 14 & 4 & 0 & 21 \\
\hline & Pedagoški fakultet & 2 & 2 & 0 & 0 & 1 & 1 & 0 & 0 & 0 & 4 & 2 & 6 \\
\hline \multirow{5}{*}{ Medicinske nauke } & $\begin{array}{l}\text { Fakultet zdravstvenih } \\
\text { studija }\end{array}$ & 1 & 1 & 1 & 0 & 0 & 0 & 0 & 10 & 0 & 0 & 0 & 10 \\
\hline & Farmaceutski fakultet & 10 & 10 & 2 & 2 & 0 & 6 & 0 & 20 & 14 & 0 & 12 & 46 \\
\hline & Medicinski fakultet & 40 & 38 & 6 & 12 & 18 & 2 & 2 & 60 & 84 & 72 & 4 & 222 \\
\hline & Stomatološki fakultet & 8 & 4 & 0 & 4 & 0 & 0 & 4 & 0 & 28 & 0 & 0 & 32 \\
\hline & Veterinarski fakultet & 12 & 12 & 6 & 2 & 3 & 1 & 0 & 60 & 14 & 12 & 2 & 88 \\
\hline \multirow{4}{*}{$\begin{array}{c}\text { Prirodno- } \\
\text { matematičke i } \\
\text { biotehničke nauke }\end{array}$} & \begin{tabular}{|l|} 
INGEB \\
\end{tabular} & 10 & 10 & 0 & 3 & 5 & 2 & 0 & 0 & 21 & 20 & 4 & 45 \\
\hline & PMF & 103 & 97 & 22 & 10 & 32 & 31 & 6 & 220 & 70 & 128 & 62 & 486 \\
\hline & $\begin{array}{l}\text { Poljoprivredno- } \\
\text { prehrambeni fakultet }\end{array}$ & 14 & 14 & 3 & 6 & 0 & 5 & 0 & 30 & 42 & 0 & 10 & 82 \\
\hline & Šumarski fakultet & 14 & 13 & 5 & 3 & 1 & 4 & 1 & 50 & 21 & 4 & 8 & 84 \\
\hline \multirow{4}{*}{ Tehničke nauke } & ETF & 9 & 9 & 1 & 2 & 2 & 4 & 0 & 10 & 14 & 8 & 8 & 40 \\
\hline & $\begin{array}{l}\begin{array}{l}\text { Fakultet za saobraćaj i } \\
\text { komunikacije }\end{array} \\
\end{array}$ & 2 & 2 & 1 & 0 & 0 & 1 & 0 & 10 & 0 & 0 & 2 & 12 \\
\hline & Građevinski fakultet & 11 & 11 & 2 & 2 & 0 & 7 & 0 & 20 & 14 & 0 & 14 & 48 \\
\hline & Mašinski fakultet & 10 & 10 & 0 & 2 & 0 & 8 & 0 & 0 & 14 & 0 & 16 & 30 \\
\hline
\end{tabular}

Tabela 5. Lista broja objavljenih radova i bodovi za 2018. godinu po grupacijama $i$ organizacionim jedinicama Univerziteta u Sarajevu prema Pravilniku o nagrađivanju.

\begin{tabular}{|c|c|c|c|c|c|c|c|c|c|c|c|c|c|}
\hline GRUPACIJA & $\begin{array}{c}\text { Organizaciona } \\
\text { jedinica/institucija }\end{array}$ & WoS Docs & $\begin{array}{c}\text { Docs in } \\
\text { JIF } \\
\text { Journals }\end{array}$ & $\begin{array}{l}\text { Docs in } \\
\text { Q1 } \\
\text { Journals }\end{array}$ & $\begin{array}{c}\text { Docs in } \\
\text { Q2 } \\
\text { Journals }\end{array}$ & $\begin{array}{c}\text { Docs in } \\
\text { Q3 } \\
\text { Journals }\end{array}$ & $\begin{array}{l}\text { Docs in } \\
\text { Q4 } \\
\text { Journals }\end{array}$ & $\begin{array}{l}\text { Docs } \\
\text { other } \\
\text { than JIF }\end{array}$ & Q1 (10) & $\mathrm{Q} 2(7)$ & Q3 (4) & Q4 (2) & $\begin{array}{l}\text { UKUPNO } \\
\text { BODOVA }\end{array}$ \\
\hline \multirow{3}{*}{ Društvene nauke } & Ekonomski fakultet & 27 & 8 & 1 & 3 & 3 & 1 & 19 & 10 & 21 & 12 & 2 & 64 \\
\hline & Fakultet političkih nauka & 5 & 2 & 0 & 0 & 2 & 0 & 3 & 0 & 0 & 8 & 0 & 11 \\
\hline & $\begin{array}{l}\text { Fakultet sporta i tjelesnog } \\
\text { odgoja }\end{array}$ & 21 & 7 & 0 & 0 & 0 & 7 & 14 & 0 & 0 & 0 & 14 & 28 \\
\hline \multirow{3}{*}{ Humanističke nauke } & Filozofski fakultet & 11 & 7 & 2 & 5 & 0 & 0 & 4 & 20 & 35 & 0 & 0 & 59 \\
\hline & $\begin{array}{l}\text { Katolički bogoslovni } \\
\text { fakultet }\end{array}$ & 1 & 0 & 0 & 0 & 0 & 0 & 1 & 0 & 0 & 0 & 0 & 1 \\
\hline & Pedagoški fakultet & 11 & 1 & 1 & 0 & 0 & 0 & 10 & 10 & 0 & 0 & 0 & 20 \\
\hline \multirow{5}{*}{ Medicinske nauke } & $\begin{array}{l}\text { Fakultet zdravstvenih } \\
\text { studija }\end{array}$ & 2 & 2 & 1 & 0 & 1 & 0 & 0 & 10 & 0 & 4 & 0 & 14 \\
\hline & Farmaceutski fakultet & 60 & 19 & 2 & 4 & 7 & 6 & 41 & 20 & 28 & 28 & 12 & 129 \\
\hline & Medicinski fakultet & 51 & 27 & 3 & 9 & 8 & 7 & 24 & 30 & 63 & 32 & 14 & 163 \\
\hline & Stomatološki fakultet & 3 & 0 & 0 & 0 & 0 & 0 & 3 & 0 & 0 & 0 & 0 & 3 \\
\hline & Veterinarski fakultet & 36 & 35 & 17 & 4 & 12 & 2 & 1 & 170 & 28 & 48 & 4 & 251 \\
\hline \multirow{4}{*}{$\begin{array}{c}\text { Prirodno- } \\
\text { matematičke i } \\
\text { biotehničke nauke }\end{array}$} & INGEB & 22 & 22 & 1 & 0 & 10 & 11 & 0 & 10 & 0 & 40 & 22 & 72 \\
\hline & PMF & 124 & 88 & 18 & 30 & 26 & 14 & 36 & 180 & 210 & 104 & 28 & 558 \\
\hline & $\begin{array}{l}\text { Poljoprivredno- } \\
\text { prehrambeni fakultet }\end{array}$ & 41 & 36 & 3 & 14 & 9 & 10 & 5 & 30 & 98 & 36 & 20 & 189 \\
\hline & Šumarski fakultet & 27 & 19 & 3 & 5 & 4 & 7 & 8 & 30 & 35 & 16 & 14 & 103 \\
\hline \multirow{4}{*}{ Tehničke nauke } & Arhitektonski fakultet & 1 & 1 & 1 & 0 & 0 & 0 & 0 & 10 & 0 & 0 & 0 & 10 \\
\hline & ETF & 33 & 27 & 2 & 6 & 10 & 9 & 6 & 20 & 42 & 40 & 18 & 126 \\
\hline & Građevinski fakultet & 24 & 16 & 3 & 1 & 2 & 10 & 8 & 30 & 7 & 8 & 20 & 73 \\
\hline & Mašinski fakultet & 32 & 10 & 0 & 3 & 3 & 4 & 22 & 0 & 21 & 12 & 8 & 63 \\
\hline Umjetnost & Muzička akademija & 2 & 2 & 0 & 0 & 2 & 0 & 0 & 0 & 0 & 8 & 0 & 8 \\
\hline
\end{tabular}


Tabela 6. Lista broja objavljenih radova i bodovi za 2019. godinu po grupacijama $i$ organizacionim jedinicama Univerziteta u Sarajevu prema Pravilniku o nagrađivanju.

\begin{tabular}{|c|c|c|c|c|c|c|c|c|c|c|c|c|c|}
\hline \multicolumn{14}{|c|}{ SAVJET ZA NAUKU I UMJETNOST UNIVERZITETA U SARAJEVU } \\
\hline \multicolumn{14}{|c|}{ UTVRDENA LISTA RADOVA I BODOVA PO ORGANIZACIONIM JEDINICAMA U SKLADU SA PRAVILNIKOM O NAGRAĐIVANJU (2019. GODINA) } \\
\hline \multicolumn{14}{|c|}{ OJ lista za nagrade } \\
\hline & & & & & & & & & & BODOI & ANJE & & \\
\hline GRUPACIJA & Organizaciona jedinica/institucija & WoS Docs & $\begin{array}{c}\text { Docs in JIF } \\
\text { Journals }\end{array}$ & $\begin{array}{c}\text { Docs in } \\
\text { Q1 } \\
\text { Journals }\end{array}$ & $\begin{array}{c}\text { Docs in } \\
\text { Q2 } \\
\text { Journals }\end{array}$ & $\begin{array}{c}\text { Docs in } \\
\text { Q3 } \\
\text { Journals }\end{array}$ & \begin{tabular}{|c|} 
Docs in \\
Q4 \\
Journals \\
\end{tabular} & $\begin{array}{c}\text { Docs } \\
\text { other } \\
\text { than JIF }\end{array}$ & Q1 (10) & Q2 (7) & Q3 (4) & Q4 (2) & $\begin{array}{l}\text { UKUPNO } \\
\text { BODOVA }\end{array}$ \\
\hline \multirow{5}{*}{ Društvene nauke } & Ekonomski fakultet & 36 & 22 & 9 & 7 & 5 & 1 & 14 & 90 & 49 & 20 & 2 & 175 \\
\hline & Fakultet političkih nauka & 5 & 1 & 0 & 1 & 0 & 0 & 4 & 0 & 7 & 0 & 0 & 11 \\
\hline & Fakultet sporta i tjelesnog odgoja & 10 & 2 & 1 & 0 & 1 & 0 & 8 & 10 & 0 & 4 & 0 & 22 \\
\hline & \begin{tabular}{|l|} 
Fakultet za kriminalistiku, \\
kriminologiju i sigurnosne studije
\end{tabular} & 2 & 1 & 1 & 0 & 0 & 0 & 1 & 10 & 0 & 0 & 0 & 11 \\
\hline & Pravni fakultet & 1 & 0 & 0 & 0 & 0 & 0 & 1 & 0 & 0 & 0 & 0 & 1 \\
\hline \multirow{4}{*}{ Humanističke nauke } & Filozofski fakultet & 18 & 1 & 1 & 0 & 0 & 0 & 17 & 10 & 0 & 0 & 0 & 27 \\
\hline & Katolički bogoslovni fakultet & 1 & 0 & 0 & 0 & 0 & 0 & 1 & 0 & 0 & 0 & 0 & 1 \\
\hline & Pedagoški fakultet & 10 & 2 & 0 & 0 & 0 & 2 & 8 & 0 & 0 & 0 & 4 & 12 \\
\hline & Institut za historiju & 2 & 0 & 0 & 0 & 0 & 0 & 2 & 0 & 0 & 0 & 0 & 2 \\
\hline \multirow{5}{*}{ Medicinske nauke } & Fakultet zdravstvenih studija & 5 & 4 & 1 & 0 & 1 & 2 & 1 & 10 & 0 & 4 & 4 & 19 \\
\hline & Farmaceutski fakultet & 46 & 26 & 2 & 0 & 10 & 14 & 20 & 20 & 0 & 40 & 28 & 108 \\
\hline & Medicinski fakultet & 108 & 87 & 28 & 6 & 20 & 33 & 24 & 280 & 42 & 80 & 66 & 492 \\
\hline & Stomatološki fakultet & 4 & 0 & 0 & 0 & 0 & 0 & 4 & 0 & 0 & 0 & 0 & 4 \\
\hline & Veterinarski fakultet & 19 & 17 & 2 & 1 & 1 & 13 & 2 & 20 & 7 & 4 & 26 & 59 \\
\hline \multirow{4}{*}{$\begin{array}{c}\text { Prirodno- } \\
\text { matematičke i } \\
\text { biotehničke nauke }\end{array}$} & INGEB & 26 & 26 & 2 & 0 & 4 & 20 & 0 & 20 & 0 & 16 & 40 & 76 \\
\hline & PMF & 131 & 105 & 8 & 35 & 28 & 34 & 38 & 80 & 245 & 112 & 68 & 543 \\
\hline & $\begin{array}{l}\text { Poljoprivredno-prehrambeni } \\
\text { fakultet }\end{array}$ & 36 & 24 & 5 & 6 & 3 & 10 & 12 & 50 & 42 & 12 & 20 & 136 \\
\hline & Šumarski fakultet & 42 & 30 & 12 & 0 & 0 & 18 & 12 & 120 & 0 & 0 & 36 & 168 \\
\hline \multirow{4}{*}{ Tehničke nauke } & ETF & 41 & 28 & 15 & 4 & 3 & 6 & 13 & 150 & 28 & 12 & 12 & 215 \\
\hline & $\begin{array}{l}\text { Fakultet za saobraćaj i } \\
\text { komunikacije }\end{array}$ & 3 & 1 & 1 & 0 & 0 & 0 & 2 & 10 & 0 & 0 & 0 & 12 \\
\hline & Građevinski fakultet & 29 & 16 & 6 & 1 & 0 & 9 & 13 & 60 & 7 & 0 & 18 & 98 \\
\hline & Mašinski fakultet & 52 & 19 & 1 & 5 & 11 & 2 & 33 & 10 & 35 & 44 & 4 & 126 \\
\hline \multirow{2}{*}{ Umjetnost } & Akademija likovnih umjetnosti & 1 & 0 & 0 & 0 & 0 & 0 & 1 & 0 & 0 & 0 & 0 & 1 \\
\hline & Muzička akademija & 1 & 0 & 0 & 0 & 2 & 0 & 1 & 0 & 0 & 8 & 0 & 9 \\
\hline
\end{tabular}

\section{Analiza broja i citiranja naučnih radova objavljenih s afilijacijom Univerziteta u Sarajevu}

U ovom dijelu rada analizira se broj i citiranje naučnih radova s afilijacijom Univerziteta u Sarajevu (adresa ustanove „Univ Sarajevo“) koji su objavljeni u časopisima koje prati baza podataka Web of Science Core Collection. Iz razmatranja su isključeni radovi s adresama: Int Univ Sarajevo, Burch Univ Sarajevo i SSST. Uzimajući u obzir da autori nisu uvijek vodili računa da se u afilijaciji navede Univerzitet u Sarajevu (ponekad je navođen samo naziv fakulteta ili odsjeka) dobijeni rezultati se ne mogu smatrati potpunim. Ipak, i ovako dobijeni rezultati ukazuju na trend razvoja naučnog rada na univerzitetu.

Na slikama 1 i 2 su prikazani broj objavljenih radova i njihova citiranost po godinama od 1949. do 2019. Mogu se uočiti četiri vremenska perioda/faze:

- Od 1949. do 1972. godine: ovo je period početaka naučnog rada na Univerzitetu u Sarajevu i broj radova i citata tih radova je mali.

- Od 1973. do 1991. godine: u ovom periodu već postoji dobra osnova za naučni rad i broj objavljenih radova i citata je znatno veći nego u prvom periodu i u blagom je porastu s godinama. 
- Od 1992. do 2004. godine: Ovo je period rata i obnavljanja naučnih potencijala nakon rata. Broj publikacija je smanjen.

- Od 2005. do 2019. godine: nakon 2005. godine dolazi do naglog povećanja broja objavljenih naučnih radova i broja citata. Ovaj porast je znatno veći od očekivanog i bilo bi korisno ispitati zašto je do toga došlo. Moguće je da je to povezano s početkom Bolonjskog procesa, uvođenjem internacionalizacije i poboljšanjem međunarodne saradnje sa drugim univerzitetima.

Slika 1. Broj objavljenih naučnih radova sa afilijacijom Univerziteta u Sarajevu po godinama (prema Web of Science Core Collection za period od 1949. do 2019. godine, pristup preko Max Born Instituta u Berlinu 2020).

Total Publications

\subsection{8 inalyze}

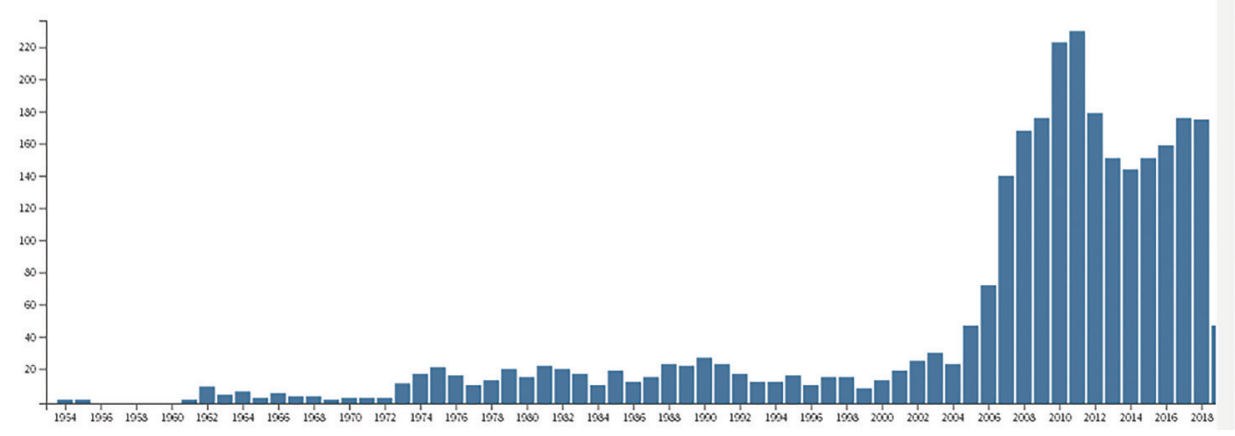

Slika 2. Broj citata za radove sa Slike 1.

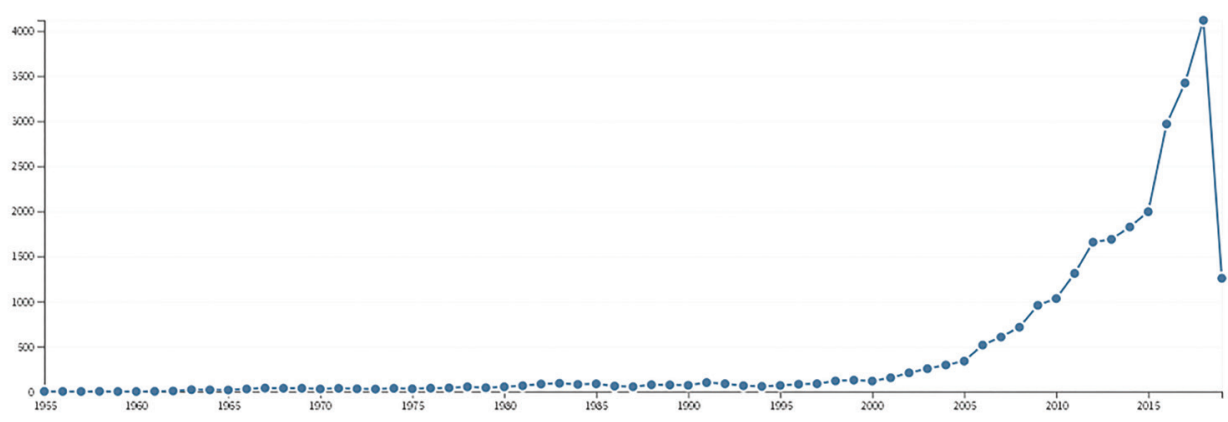

Na Slici 3 je predstavljena analiza broja i citiranja radova sa afilijacijom Univerziteta u Sarajevu prema Web of Science Core Collection za period 
od 1994. do 2020. godine (pretplata Univerziteta u Sarajevu uključuje ovaj period). Vidimo da je objavljeno preko 4000 radova i da je od 2007. godine broj radova naglo porastao. Nakon izvjesne stagnacije u periodu 2012-2014. godina broj radova i njihova citiranost je u stalnom porastu. Ova analiza ukazuje da je, i pored loših uslova u kojima se odvija naučnoistraživački rad, naš doprinos svjetskoj naučnoj produkciji u porastu.

Slika 3. Broj objavljenih radova po godinama od 1994. do 2020. godine. ${ }^{12}$

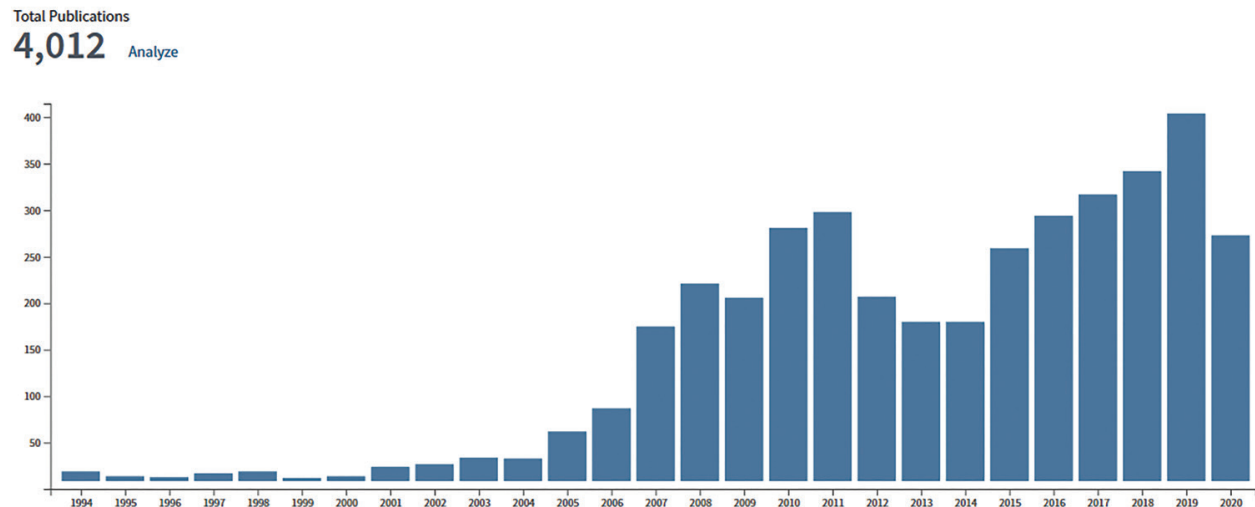

Slika 4. Broj citata po godinama za radove sa Slike 3.

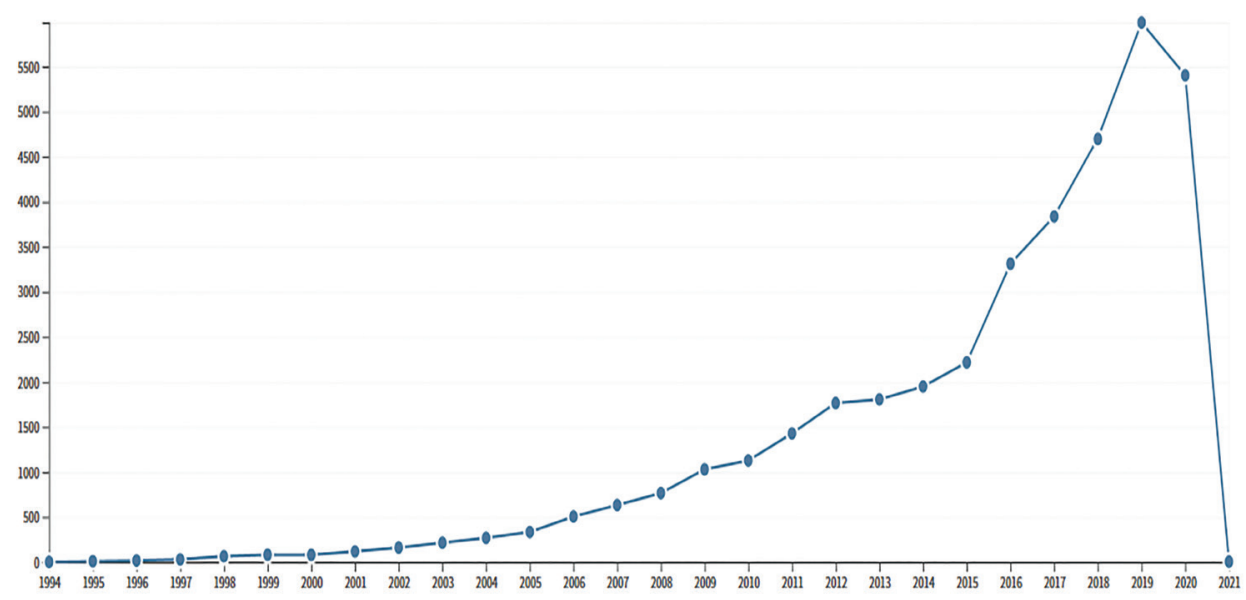

${ }^{12}$ Citation report WoSCC (2020., ORGANIZATION-ENHANCED: (University of Sarajevo) NOT TOPIC: (Int Univ Sarajevo) NOT TOPIC: (Burch). Indexes: SCI-EXPANDED, SSCI, A\&HCI, ESCI). 


\section{Instituti, naučnoistraživački centri i tehnološki parkovi}

Prema Odgovorima na dodatna pitanja iz Upitnika Evropske komisije ${ }^{13} \mathrm{u}$ Federaciji Bosne i Hercegovine djeluje oko 20 instituta u sklopu fakulteta ili univerziteta i desetak instituta u svojstvu samostalnih pravnih lica. Korištena terminologija (,oko“, „,desetak“) ukazuje na problem nepostojanja jasnog načina prikupljanja osnovnih podataka o institutima. Kako se onda može očekivati poboljšanje položaja tih instituta? Nešto preciznije su informacije za Republiku Srpsku. U tom entitetu djeluje ukupno 30 instituta, od čega je 12 instituta pri javnim univerzitetima, osam instituta pri privatnim univerzitetima te deset samostalnih instituta.

U pomenutoj Strategiji razvoja naučnoistraživačkog/umjetničkoistraživačkog rada na Univerzitetu u Sarajevu, tehnološki/naučno-tehnološki parkovi su definisani kao organizacije čiji je osnovni zadatak da promoviraju inovativnost $\mathrm{i}$ kooperativnu aktivnost poduzetnika i istraživačkih institucija s potencijalom podizanja nivoa konkurentnosti. Te organizacije upravljaju protokom znanja i tehnologija između univerziteta, istraživačko-razvojnih institucija i privrednih subjekata. Time se omogućava kreiranje i uspostava kompanija baziranih na inovacijama i to kroz spin-off i startup privredne subjekte. Primarni zadatak takvih centara je generiranje inovativnih rješenja koja proizlaze iz djelatnosti naučnoistraživačkih subjekata (fakulteta, akademija, instituta, laboratorija, zavoda itd.) i uspostava veze i translacija inovacija u privredni sektor." Prema pomenutim Odgovorima na dodatna pitanja iz Upitnika Evropske komisije, u Federaciji Bosne i Hercegovine trenutno postoje četiri tehnološka parka: „Technopark“ u Zenici, „INTERA“ u Mostaru, „BIT centar“ u Tuzli i „HUB 387“ u Sarajevu. Pitanje je koliko se navedeni tehnološki parkovi uklapaju u gore navedenu definiciju naučno-tehnoloških parkova. U Republici Srpskoj djeluje Inovacioni centar Banja Luka (ICBL) koji podržava razvoj preduzeća s potencijalom da tržištu ponude komercijalna rješenja u vidu proizvoda, usluga i unapređenja poslovnih procesa, zasnovanih na znanju i primjeni inovativnih i naprednih tehnologija. Ministarstvo nauke i tehnologije vodi Registar pravnih i fizičkih lica koja se bave razvojem tehnologija. Organizacije za infrastrukturnu podršku razvoju tehnologija su: Fondacija inovacioni centar Banja Luka, Univerzitetsko-preduzetnički centar Banja Luka, Biznis inkubator Gradiška, Tehnološki biznis park Banja Luka

\footnotetext{
${ }^{13}$ Vidjeti: Odgovori na Upitnik Evropske komisije - Poglavlje 25 - Nauka i istraživanje, Direkcija za evropske integracije Vijeća ministara Bosne i Hercegovine, DEI | Odgovori na Upitnik EK.
} 
(od 2015. transformisan u poslovnu zonu „Ramići-Banja Luka“) i Tehnološki centar „LANACO“ Banja Luka.

Među navedenim institutima, naučnoistraživačkim centrima i tehnološkim parkovima ne spominje se novoosnovani Centar za istraživanje i razvoj (R\&D centar) Univerziteta u Sarajevu, kao ni javna ustanova „Centar za napredne tehnologije u Sarajevu“. Za implementaciju strateških ciljeva pomenute Strategije razvoja naučnoistraživačkog/ umjetničkoistraživačkog rada na Univerzitetu u Sarajevu bitno je uspostavljanje Centra za istraživanje i razvoj „koji će doprinijeti etabliranju Univerziteta u Sarajevu kao vodeće institucije $u$ istraživanju, kreiranju i realizaciji naučnih i razvojnih projekata, te promoviranju inovativnosti i izvrsnosti, kao i jačanju saradnje s javnim, privatnim i nevladinim sektorom u našoj zemlji. S druge strane, apliciranjem i implementacijom EU i drugih međunarodnih projekata, ali i intenzivnijom saradnjom s privrednim sektorom obezbijedit će se značajni resursi za finansijsku i drugu vrstu podrške ne samo aplikativnim već i fundamentalnim istraživanjima te profesionalnom razvoju i većoj mobilnosti naučnika i istraživača. Zasigurno će uspostavljanje ovakvog centra pospješiti integriranost Univerziteta u Sarajevu u Evropski prostor visokog obrazovanja - European Higher Education Area (EHEA) i Evropski istraživački prostor - European Research Area (ERA) te ojačati R\&D saradnju u međunarodnim okvirima. Centar za istraživanje i razvoj UNSA će biti integrirani centar koji će uključivati tri temeljna područja:

- inovacije, inkubator i naučno/tehnološki park kroz „Open innovation” model koji predstavlja sve zastupljeniji model organizacije i upravljanja inovacijama, a podrazumijeva R\&D saradnju svih ključnih stakeholdera u cilju kreiranja potpuno novih proizvoda, procesa i sl. Osim adekvatne podrške start-up projektima, R\&D centar će koordinirati i njihovu implementaciju, te komercijalizaciju inovacija kroz spin-off kompanije. Ova komponenta podrazumijeva značajnu uključenost mladih istraživača i studenata;

- izvrsnost i institucionalizirani pristup razvitku i prenosu najboljih praksi uključujući podršku nastavnom i istraživačkom osoblju UNSA u kontekstu njihovog profesionalnog razvoja, istraživanja, edukacije, zaštite intelektualnog vlasništva (spin-off) itd.;

- EU i domaći projekti: većina realiziranih projekata, bilo da je riječ o međunarodnim (EU) ili domaćim projektima, ovisi o individualnom angažmanu pojedinih istraživača bez ikakve sistemske podrške. Tako- 
Dejan Milošević, Benjamin Fetić: Teškoće u unapređenju nauke i oblikovanju sistema nauke i univerziteta...

đer, nesrazmjerno je veliki broj projekata u kojim UNSA ima ulogu partnerske institucije, a ne ulogu koordinatora ili pak vodećeg partnera. Uspostavljanjem centra za istraživanje i razvoj UNSA, kao integriranog mehanizma institucionalne podrške projektnim aktivnostima na našem Univerzitetu, taj omjer bi se značajno poboljšao, a poseban doprinos kvalitetu pisanih i realiziranih projekata bio bi obezbijeđen kroz multidisciplinarne projektne timove kao i savremene mehanizme upravljanja portfoliom projekata uz racionalnije korištenje resursa.“

\section{Statistički podaci o naučnoistraživačkom radu. Patenti}

Agencija za statistiku $\mathrm{BiH}$ publikuje saopštenje „Patenti“ kao rezultat obrade podataka preuzetih od Instituta za intelektualno vlasništvo Bosne i Hercegovine. Podaci su dobijeni prema definisanim tabelama i obrađeni prema zadanoj metodologiji. U Tabeli 7 su prikazani patenti u periodu 2010 2016. Interesantno je uočiti da je broj stranih prijavitelja znatno veći nego broj domaćih prijavitelja patenata. Pored toga, broj patenata kontinuirano opada. Očito je da naše društvo ne stimuliše inovacije i patente. U 2019. godini je priznato šest patenata u nacionalnom postupku, od čega je samo jedan domaći prijavitelj i pet stranih prijavitelja. ${ }^{14}$

Tabela 7. Patenti priznati u nacionalnom postupku, BiH 2010-2016.

\begin{tabular}{lccccccc}
\hline & 2010. & 2011. & 2012. & 2013. & 2014. & 2015. & 2016. \\
\hline Ukupno & 207 & 148 & 99 & 85 & 45 & 30 & 13 \\
\hline Domaći prijavitelji & 29 & 36 & 16 & 7 & 2 & 12 & 0 \\
\hline Fizičke osobe & 28 & 34 & 16 & 6 & 2 & 11 & 0 \\
\hline Pravne osobe & 1 & 2 & 0 & 1 & 0 & 1 & 0 \\
\hline Strani prijavitelji & 178 & 112 & 83 & 78 & 43 & 18 & 13 \\
\hline Fizičke osobe & 7 & 5 & 4 & 5 & 0 & 0 & 2 \\
\hline Pravne osobe & 171 & 107 & 79 & 73 & 43 & 18 & 11 \\
\hline
\end{tabular}

Analizom sadržaja predstavljenih na web stranici Agencije za statistiku Bosne i Hercegovine ${ }^{15}$ zaključili smo da bi trebalo poboljšati način prikupljanja statističkih podataka o naučnoistraživačkoj djelatnosti. Npr., prema saopćenju Agencije za statistiku Bosne i Hercegovine, ${ }^{16}$ broj naučnih radova

\footnotetext{
${ }^{14}$ http://bhas.gov.ba/data/Publikacije/Saopstenja/2020/EDU_06_2018_Y1_0_BS.pdf

${ }^{15}$ www.bhas.gov.ba

${ }^{16}$ http://bhas.gov.ba/data/Publikacije/Saopstenja/2019/RDE_01_2018_Y1_0_BS.pdf
} 
objavljenih u visokom obrazovanju u 2018. godini iz oblasti prirodnih nauka je 18. Međutim, stvarni broj bi trebao biti daleko veći. Toliko radova je objavio sam Odsjek za fiziku Prirodno-matematičkog fakulteta u Univerziteta Sarajevu. Prirodno-matematički fakultet (PMF) i Institut za genetičko inženjerstvo i biotehnologiju (INGEB) su, prema Tabeli 5, objavili u 2018. godini 146 radova iz prirodnih nauka (ovi radovi su bili osnova za nagrađivanje i registrovani su u bazi Web of Science Core Collection; ako se uzmu u obzir i druge manje značajne baze, broj objavljenih radova je znatno veći).

\section{Finansiranje i problemi realizacije zapošljavanja naučnika i istraživača}

U ovom radu se ne analiziraju problemi finansiranja naučnoistraživačkog rada u Bosni i Hercegovini, već se ukazuje na to da, čak i ako se dobiju sredstva za naučnoistraživačka radna mjesta, problem predstavlja nepostojanje mehanizama za realizaciju zapošljavanja (potrebno je odobrenje vlade, odnosno nadležnih vlasti, a one ograničavaju broj radnih mjesta). Zakonsku regulativu i „društvenu atmosferu“ treba mijenjati paralelno s odobravanjem sredstava za nauku. Uzimajući u obzir mali broj mladih naučnika i istraživača u Bosni i Hercegovini, bilo bi posebno značajno planirati finansijska sredstva iz budžeta za obezbjeđivanje naučnoistraživačkog podmlatka, odnosno zapošljavanje mladih asistenata $\mathrm{i}$ istraživača. Paralelno bi trebalo raditi na mijenjanju kadrovske politike, razvijanju međunarodne saradnje (s posebnim naglaskom na našu naučnu dijasporu) i uvesti posebne mjere koje bi omogućile povratak najboljih studenata i naučnika u Bosnu i Hercegovinu.

\section{Zaključci}

U ovom radu je ukazano na neke od mogućnosti otklanjanja poteškoća $\mathrm{s}$ kojima se sreću bosanskohercegovački univerziteti pri unapređenju nauke i oblikovanju sistema nauke i naučnoistraživačkog rada. Na rang listi država u svijetu prema The SCImago Journal \& Country Rank portalu Bosna i Hercegovina se trenutno nalazi na 90. mjestu, a najbolje plasirani univerzitet u Bosni i Hercegovini prema Webometricsu je Univerzitet u Sarajevu (1508. mjesto). Ovi rezultati, ako se uzmu u obzir specifično ustavno i teritorijalno uređenje Bosne i Hercegovine i problemi uzrokovani ratom i poslijeratnom tranzicijom, i nisu tako loši. Ipak, zaostajanje u odnosu na susjedne države Hrvatsku i Srbiju je preveliko i nužne su promjene. U okviru projekta 
„Harmonizacija sistema nauke u Bosni i Hercegovini““ Akademije nauka i umjetnosti Bosne i Hercegovine akcenat je na harmonizaciji sistema nauke putem zakonodavstava nadležnih teritorijalnih jedinica u Bosni i Hercegovini. U ovom radu naglasak je na alternativnom pristupu poboljšanju položaja nauke i naučnoistraživačkog rada u Bosni i Hercegovini. To je „bottom-up“ pristup prema kojem sami univerziteti, instituti i drugi nosioci razvoja nauke i naučnoistraživačkog rada, kao i sami pojedinci koji se bave naučnoistraživačkim radom, mogu mnogo učiniti da se poboljša položaj nauke, ne čekajući izmjene postojećih i donošenje novih zakona. Kao primjeri takvog pristupa navedeni su Strategija razvoja naučnoistraživačkog rada i Pravilnik o nagrađivanju na osnovu rezultata naučnoistraživačkog rada na Univerzitetu u Sarajevu. Pored toga, koristeći primjere statističkih podataka o naučnoistraživačkom radu i patentima (postoji samo jedan priznati domaći patent $\mathrm{u}$ Bosni i Hercegovini u 2019. godini) ukazano je na potrebu poboljšanja načina prikupljanja statističkih podataka o naučnoistraživačkom radu. Nadamo se da će ovaj rad i navedeni primjeri poslužiti kao putokaz kako se individualnim naporima i djelovanjem samih univerziteta i instituta može poboljšati položaj nauke u Bosni i Hercegovini.

\section{Literatura}

Trifković, M. (2020). Harmonizacija sistema nauke u Bosni i Hercegovini. Akademija nauka i umjetnosti Bosne i Hercegovine. Posebna izdanja. Knjiga CLXXXV. Centar za sistemska istraživanja. Knjiga 5/1. Sarajevo.

Guerrero-Botea, V. P. i Moya-Anegón, F. (2012). A further step forward in measuring journals' scientific prestige: The SJR2 indicator. Journal of Informetrics, Vol. 6, str. 674-688. ISSN: 1751-1577 